\title{
On the Scattering and the Attenuation of Light in the Sea Water*
}

\author{
Kozo HisHIDA**
}

\begin{abstract}
The scattered light in the directions of $45^{\circ}, 90^{\circ}$ and $135^{\circ}$ and the attenuated light were measured in the laboratory for the sea water samples taken in and off Maizuru Bay in the Japan Sea. One example is introduced to show the states of optical water mass in these regions. Relations of the scattered light flux in the direction of $90^{\circ}$ to that in the directions of $45^{\circ}$ and $135^{\circ}$ were studied. The change of scattered light flux with the wave-length of light and the relation between the scattering and the attenuation were discussed with Mie scattering theory. It is seen that the average diameter of suspended particles is about $1 \mu$ and their refractive index $\mathrm{m}=1.25$, and that the scattering by these particles may take a greater portion in the attenuation of light.
\end{abstract}

\section{Introduction}

The relative scattering and related extinction of light in the sea water samples have been used to characterize and trace water masses in the sea. (JERLOV, 1953; JOSEPH, 1953) Angular distributions of scattered light have beer also studied in the laboratory and also in the ocean in situ by several authors. (TYLER and RICHARDSON, 1958; IVANOFF, 1959; SASAKI, et al., 1960, 1962)

The investigation of the scattered light with special reference to the attenuated light in the sea water was attempted by the author. Measurements of the scattered light in three clirections, related to the transmitted light were carried out with the sea water samples taken from the vicinity of Maizuru in the Japan Sea about ten years ago, while recently, the suitable table of light scattering function (PANGONIS and HELLER, 1960) has been got, and then, some theoretical considerations upon the results of measurement are to be made. In this report, the experimental results with theoretical analysis will be introduced.

\section{Method and an example of results}

Fig. 1 is a schematic presentation of the apparatus that has been used for determining the angular scattering coefficient and the attenuation coefficient of light through the sea water samples. The apparatus consists of the light source, the

* Received Oct. 30, 1965

** Meteorological Research Institute sample cell and the light receivers. The cell has the shape as shown in the figure so that we may measure the scattered light flux in three scattering angles $\left(45^{\circ}, 90^{\circ}\right.$ and $\left.135^{\circ}\right)$ and also

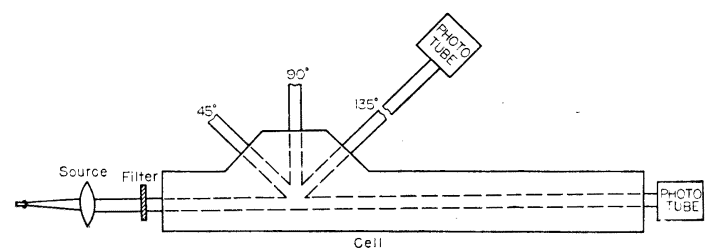

Fig. 1. A block diagram of the apparatus used.

the transmitted light flux after traversing a distance $l=20 \mathrm{~cm}$ from the incident light beam of the highly collimated light source. The phototubes used in this apparatus are the ordinary phototube (Toshiba 7209) for the transmitted light and the multiplier phototube (Toshiba MS-6SY) for the scattered light respectively. The photosignal is amplified by the $\mathrm{D}$. C. circuit and the output is read by the microammeter.

The transmitted and scattered lights are measured through the distilled water at first and then through the sea water samples. And then, the differences between the values in both cases may be considered as a measure for the attenuation and scattering coefficient of the suspended particles in the the sea water.

Sea water samples were taken several times at stations in and off Maizuru Bay in the Japan Sea as shown in Fig. 2 and measurements of transmitted and scattered light through these 
samples were carried out by this method. The colour filter used here was yellow and its center wave-length was about $560 \mathrm{~m} \mu$. The results will be reported in detail in another paper, and

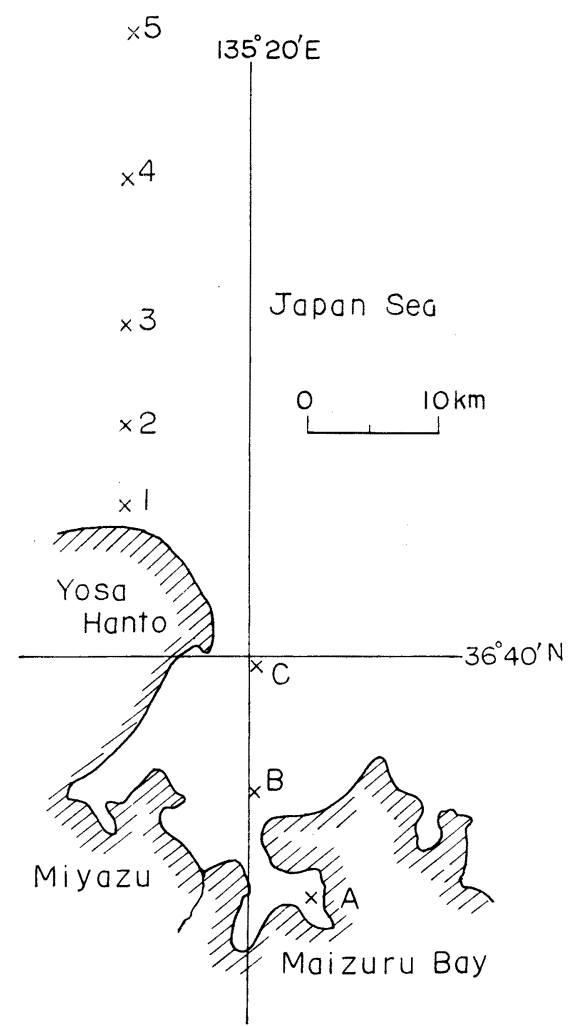

Fig. 2. Location of observed stations.

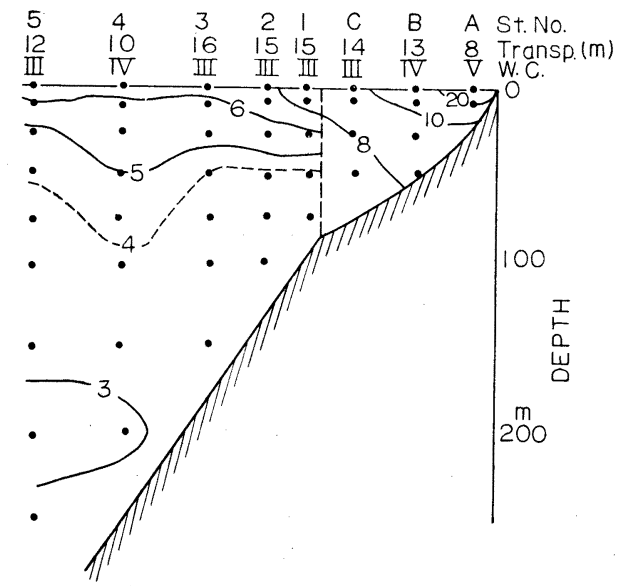

Fig. 3. Profile of scattering coefficient at scattering angle $135^{\circ}$ (unit : $10^{-5} / \mathrm{cm}$ ) with transparency and water colour. only an example is introduced to show the optical water masses characterized by the scattered light. Thus, the profile of scattering coefficient in $135^{\circ}$ direction along the stations carried on 12 May 1956 is demonstrated with the observed transparency and water colour in Fig. 3. It is seen from this figure that the most turbid water was found in Maizuru Bay, and the water was clearer in the ocean than in the bay on the basis of the values of scattering coefficient and that these values in the surface layer may be fairly correlated to the values of transparency.

\section{Theoretical back grounds}

The angular Mie scattering coefficient is defind as

$$
\beta_{\theta}=\pi r^{2} N i_{\theta}=\frac{N}{2 k^{2}}\left\{i_{1}(\alpha, n, \theta)+i_{2}(\alpha, n, \theta)\right\},
$$

where $n=$ index of refraction (of the particle against water)

$r=$ radius of spherical particle

$\lambda=$ wave-length of incident light in the water

$\alpha=2 \pi r / \lambda=k r=$ size parameter

$k=2 \pi / \lambda=$ wave number

$\theta=$ scattering angle (the angle between

the direction of propagation of the incident wave and the scattered wave) and the quantities $i_{1}$ and $i_{2}$ are intensity functions and refer to the intensity of light vibrating perpendicularly and parallel to the plane through the directions of propagation of the incident and scattered beams. (PENNDORF, 1962) They are the complicated functions of $\alpha, n$ and $\theta$, and so their numerical values may be taken from the tables by W. J. PANGONIS and W. HELlER in this paper. The quantity $i_{\theta}$ is the angular Mie scattering coefficient as follows:

$$
i_{\theta}=\left(i_{1}+i_{2}\right) / 2 \pi \alpha^{2},
$$

The function $\beta_{\theta}$ is the ratio of the flux scattered by a unit volume containing a homogeneous suspended matter of $N$ particles of radius $r$ into unit solid angle $\omega$ in the direction $\theta$, to the flux incident on the unit cross section of this volume; its dimension is $\mathrm{cm}^{-1} / \mathrm{sr}$.

The total volume scattering is obtained from the equation (1) by integrating over all direction $\theta$, and we have 


$$
\begin{aligned}
\beta & =2 \pi \int_{0}^{\pi} \beta_{\theta} \sin \theta d \theta \\
& =\frac{\pi r^{2} N}{\alpha^{2}} \int_{0}^{\pi}\left(i_{1}+i_{2}\right) \sin \theta d \theta \\
& =\pi r^{2} N K,
\end{aligned}
$$

where $K$ is the total Mie Scattering coefficient, which is defined as the ratio of the total scattering flux to the incident flux, and then,

$$
\begin{aligned}
K & =2 \pi \int_{0}^{\pi} i_{\theta} \sin \theta d \theta \\
& =\frac{1}{\alpha^{2}} \int_{0}^{\pi}\left(i_{1}+i_{2}\right) \sin \theta d \theta,
\end{aligned}
$$

The intensity of a parallel beam of light is attenuated, if only by scattering, in traversing uniform spherical suspended particles, all of radius $r$, according to the transmission equation as

$$
I / I_{0}=e^{-K \pi r^{2} N l},
$$

where $I_{0}$ is the intensity of the incident parallel beam and $I$ the intensity of the beam after traversing a distance $l$ through the medium containing $N$ particles per unit volume. Strictly speaking, $K$ is based on the total amount of light scattered by a particle in all directions, while in measurement, the amount of light scattered by a particle within acone of half-angle $\delta$ in the forward direction is added to the flux of the beam after traversing (GUMPRECHT and SLIPCEVICH, 1953). And thus, by inserting the correction factor shown as

$$
R=1-\frac{1}{K \alpha^{2}} \int_{\pi-\delta}^{\pi}\left(i_{1}+i_{2}\right) \sin \theta d \theta
$$

into the equation (5) and by the use of (3), the following results

$$
I / I_{0}=e^{-R k \pi r^{2} N l}=-R \beta l .
$$

If the absorption of light due to the suspended particles in the sea water is taken into considration, the attenuation coefficient $\tau$ is to be considered on behalf of $\beta$ in this eqation.

\section{Angular distributions of scattered light}

In this measurement, the width and height of the incident light beam are taken $b$ and $h$ respectively and the scattered light flux is received at the surface of the same area $b h$ as that of incident beam at a distance $d$ from the intersection point of the center axis in the incident light beam and the scattered light flux at scattering angle $\theta$, as shown in Fig. 4 . The values of $b, h$ and $d$ are taken $1 \mathrm{~cm}, 2 \mathrm{~cm}$ and $13 \mathrm{~cm}$ respectively. The volume $V$ related to the scattering in the direction $\theta$ may be considered from the figure to be given by

$$
V=a b h,
$$

where $a$ is the length of the volume along the incident beam and changes with $\theta$. In this case, the values of $a$ at scattering angles $45^{\circ}, 90^{\circ}$ and $135^{\circ}$ may be approximately taken as $2.0 \mathrm{~cm}$, $1.4 \mathrm{~cm}$ and $2.0 \mathrm{~cm}$ respectively by considering the half of the sum of the hatched areas in the both sides of the cross-hatched area, together with the cross-hatched area shown in Fig. 4.

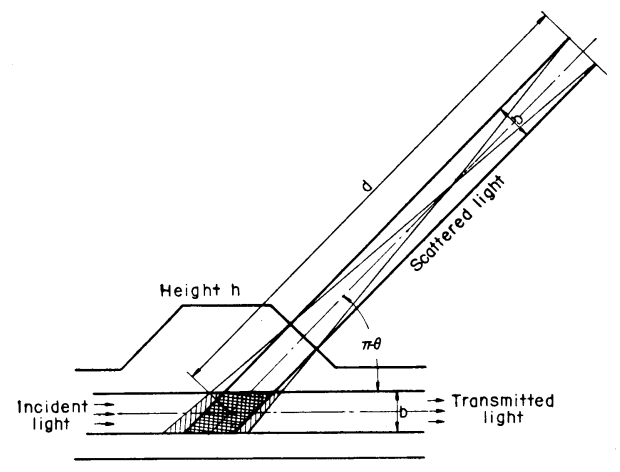

Fig. 4. Details of the system of the apparatus.

In this case, the angular volume scattering function $\beta_{\theta}$ may be proportional to the values of $\left(i_{1}+i_{2}\right)$ from the equation (1) theoretically. On the other hand, $\beta_{\theta}$ may be considered proportional to the product of $a$ in the equation (8) and the readings of the ammeter $j$ due to the photosignal of scattered light flux experimentally. From the result in the measurement of scattered light flux in $45^{\circ}, 90^{\circ}$ and $135^{\circ}$ directions through the sea water samples as mentioned before, we obtain Fig. 5, where the scales of both axes show the readings of the ammeter.

From the graph (A) in this figure which shows the relation between the value of readings in $90^{\circ}$ direction, $j_{90}$ and that in $45^{\circ}$ direction $j_{45}$, the ratio $j_{45} / j_{90}$ may be about 1.0 . From 
the graph (B) which shows the relation of $j_{90}$ to $j_{135}$, the value of readings in $135^{\circ}$, the ratio of $j_{135}$ to $j_{90}$ may be devided in two groups. For the smaller range corresponding to the clearer offshore water, the ratio may be $1: 13$, while for the larger range which shows the turbid bay water or coastal water, it may be

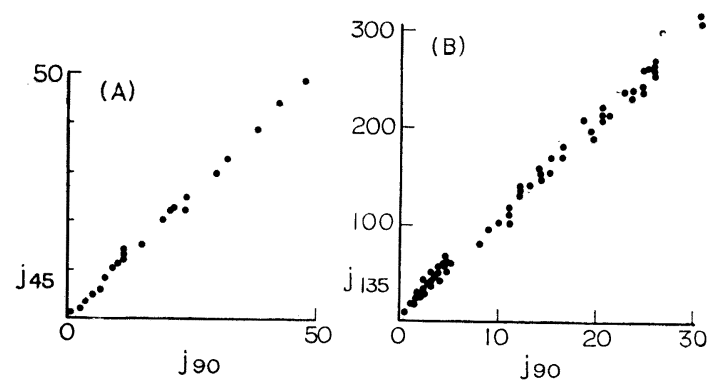

Fig. 5. Relations between scattered light flux in 3 directions (Scales : readings of ammeter due to photosignal)

(A) Between $90^{\circ}$ and $45^{\circ}$

(B) Between $90^{\circ}$ and $135^{\circ}$

$1: 10$. The difference between two case may be considered perhaps due to the lower accuracy in the smaller range, and it is now in question to conclude simply that the features in offshore water may be different from those in bay water.

And then, in this experiment we obtain the ratio of volume scattering coefficients between $45^{\circ}$, and $90^{\circ}$ and $135^{\circ}$ directions as follows:

$$
\beta_{45}: \beta_{90}: \beta_{135}=0.7: 1: 6.5 \sim 8.4 .
$$

Comparing to the theoretical ratio of $0.68: 1: 6.9$, where the values of $\left(i_{1}+i_{2}\right)$ in three directions are taken as the case of $n=1.25$ and $\alpha=5.8$ in the table before mentioned (in $135^{\circ}$ direction $140^{\circ}$ only, the mean value between $130^{\circ}, 135^{\circ}$, and is adopted), the average diameter of suspended particles may be considered about $1 \mu$ and there fractive index $n$ is coincident with the result by T. SASAKI, et al. (1962).

5. Changes of scattered light with wave-lengths The manner in which the scattered light flux changes with its wave-lengths may be easily known only by changing the colour filters in this experiment. And thus, the relation between the yellow and the blue colour is obtained as shown in Fig. 6, where the readings of ammeter by the photosignal in these two colours, $j_{Y}$ and
$j_{B}$ respectively, are taken in both axes for the clearer water and for the turbid water. These two values seem to have a linear relation and the ratio between them is nearly equal for two cases of water. The similar relations are also obtained in the other different colours, though the ratio is different. Considering the transmission rate through the colour filters, we may obtain the changes of scattered light intensity with its wave-length as shown in Fig. 7, where relative intensities are taken as a function of size parameter $\alpha=2 \pi / \lambda$.

From equations (1) and (2), the angular volume scattering coefficient $\beta_{-}$is proportional to the value of $\left(i_{1}+i_{2}\right) / \alpha^{2}$, which is shown also in Fig. 7 by adopting $n=1.25$ same as mentioned

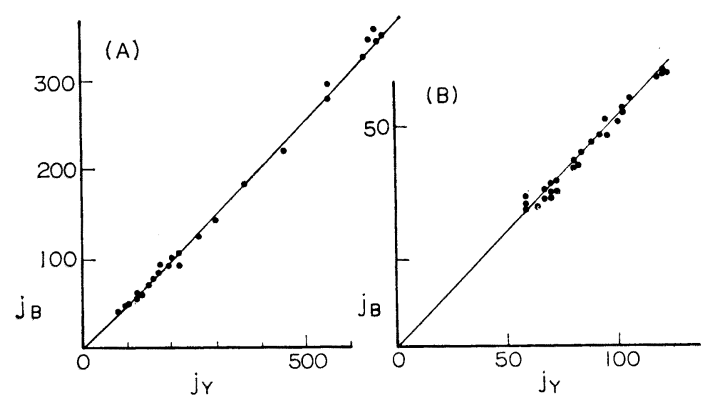

Fig. 6. Relations between the scattered light of yellow colour $j_{Y}$ and that of blue colour $j_{B}$. (Scale: readings of ammeter due to photosignal)

(A) For the turbid water

(B) For the clearer water

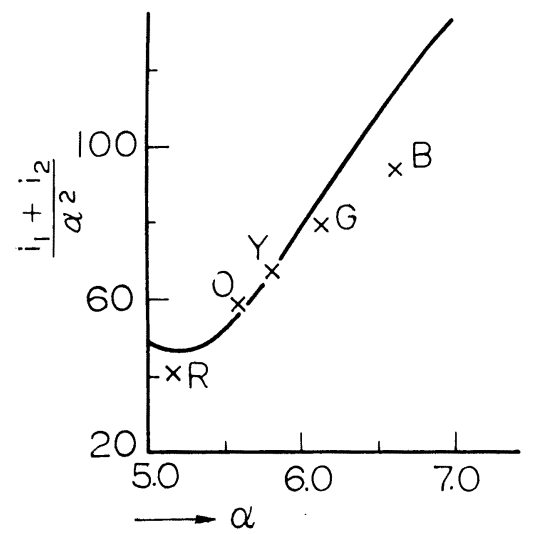

Fig. 7. Changes of scattered light intensity with its wave lengths. The marks $\times$ show the measured values for the red, orange, yellow, green and blue colours, and the curve the theoretical value. 
before and by coinciding the experimental value for the yellow light with the value of $\left(i_{1}+i_{2}\right) / \alpha^{2}$. It may be said that experimental results are in some degrees fitted to the theoretical deduction.

\section{The relation between scattering and attenu- ation}

Since the solid angle is $b h / d$ and the volume is given by the equation (8) in this experiment, the angular volume scattering coefficient $\beta_{\theta}$ may be evaluated from its definition by the following equation

$$
\beta_{\theta}=\frac{d^{2}}{a b h} \frac{F_{s}}{F_{0}},
$$

where $F_{s}$ is the intensity of scattered light at a distance $d$, and $F_{0}$ that of incident light. Taking the values of $a, b, h$ and $d$ as shown before and using that the ratio of amplified rate of photosignal by the incident light to that by the scattered light is $4.0 \times 10^{5}$, the angular volume scattering coefficient at scattering angle $135^{\circ}$ is represented from (10) as

$$
\beta_{135} \fallingdotseq 1.4 \times 10^{-6} j_{135},
$$

when the incident light flux is constant and the readings of ammeter due to its photosignal is equal to 75 in this experiment.

From equations (1) and (3), the following results

$$
\beta_{\theta} / \beta=\left(i_{1}+i_{2}\right) / 2 \pi \alpha^{2} K \text {. }
$$

By this equation, the total volume scattering coefficient is obtainable from the angular scattering coefficient. And thus, by assuming the same values of $n=1.25$ and $\alpha=5.8$ as in the case before mentioned, the total volume scattering coefficient may be given from (11) by

$$
\beta=3.9 \times 10^{-5} j_{135} .
$$

On the other hand, the relations between the readings $j_{s}$ and the attenuation coefficient $\tau$ were determined by measurements and the result is shown in Fig. 8. In this case, the correction factor $R$ in the equation (6) is taken 0.87 by the approximate computation. Using the equation (13), the total scattering coefficint $\beta$ is also shown as a line in this figure, from which we are led to the conclusion that the scattering of light may be said to take a greater part in the attenuation of light, as though the various experimental errors and the theoretical assumptions are considered in the process and the procedure of the approach shown above.
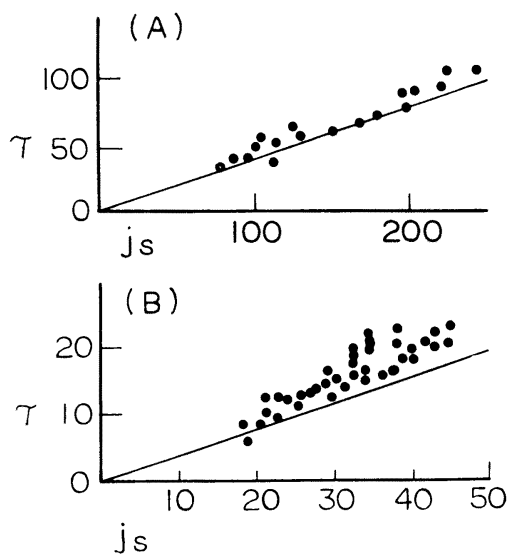

Fig. 8. Relations between readings of ammeter due to the photosignal of scattered light at scattering angle $135^{\circ}$ and the attenuation coefficient (unit : $10^{-4} / \mathrm{cm}$ ).

(A) For the turbid water

(B) For the clearer water.

Points indicate the attenuation coefficient and lines the scattering coefficient.

\section{Acknowledgements}

The authors are much indebted to the late Mr. Y. HONDA and the members of Maizuru Marine Observatory.

\section{References}

Gum.PREChT, R. O. and C. M. SLIPCEVICH (1953): Scattering of light by large spherical perticles. Jour. Phys. Chem., 57, 90-95.

IVANOFF, A. (1959): Optical method of investigation of the ocean: The $p-\beta$ diagram. Jour. Opt Soc. Amer., 49, 103-104.

JERLOV, N. G. (1953): Particle distribution in the ocean. Reports of the Swedish Deep-See Expedition, Vol. III, Physics and Chemistry, No. 3.

JosePH, J. (1953): Die Trübungsverhältnisse in der südwestlichen Nordsee, während der "Gauss"-Fahrt im Feb./März 1952. Ber, dtsch. Komm. Meeresforsch., 13 (2), 93-103.

PANGONis W. J. and W. Heller (1960): Angular scattering function for spherica! particles. Wayne State Univ. Press, 1-122.

PENNDORF, R. (1962): Angular Mie Scattering. Jour. Opt. Soc. Amer., 52, 408. 
Sasaki, T., N. Okami, G. Oshiba and S. Watanabe (1960): Angular distribution of scattered light in deep sea water. Records of Oceanogr. Works in Japan, 5, 1-10.

Sasaki, T., N. Okami, G. Oshiba and S. Watanabe (1962): Studies on suspended particles in deep sea water. Sci. Pap. Inst. Phys. Chemi. Res., 56, 77-83.

TYler, J. E. and W. H. Richardson (1958): Nephelometer for the measurement of volume scattering function in situ. Jour. Opt. Soc. Amer., 44, 631-634.

\section{海水中における光の散乱と消散}

\section{菱田耕造}

海水中に打ける透過光と $45^{\circ}, 90^{\circ}$ および $135^{\circ}$ の 3 方向の散乱光とを同時に測定する装置を作り, 日本海の 舞鶴湾およびその沖合において採取した海水について実 験室で測定を行なった。
測定結果を Mie の散乱理論を基にして, 検討を行な った結果, 浮遊粓子の平均半径はその屈折率 $\mathrm{m}=1.25$ と して約 $1 \mu$ 程度であり, また海水中における消散のかな りの部分は散乱によるものと考えられた。 